RASĀYAN J. Chem.

Vol. 13 | No. 1 |521 - 528| January - March | 2020 ISSN: 0974-1496 | e-ISSN: 0976-0083 | CODEN: RJCABP

\title{
BINUCLEAR TRANSITION METAL COMPLEXES DERIVED FROM 3, 3'-DIHYDROXY BENZIDIENE AND 2-AMINO THIO PHENOL: SPECTROSCOPIC, THERMOGRAVIMETRIC, DNA CLEAVAGE, AND ANTIMICROBIAL STUDIES
}

\author{
Kuttiyapillai Sivakumar ${ }^{1}$ and Venkatachalam Chandrasekaran ${ }^{2, *}$ \\ ${ }^{1}$ Department of Chemistry, V.S.B.Engineering College, Karur-639 111, Tamilnadu, India. \\ ${ }^{2}$ Department of Chemistry, Government Arts College (A), Salem-636 007, Tamilnadu, India. \\ *E-mail: chandru_v_m@yahoo.co.in
}

\begin{abstract}
In this novel paper, we synthesized binuclear complexes of metal chloride of $\mathrm{Cu}(\mathrm{II}), \mathrm{Ni}$ (II) with organic compounds 3,3'-dihydroxy benzidiene and 2-amino thiophenol. The type of complex is $\left[\mathrm{LM}_{2} \mathrm{Cl}_{4}\right]$. The characterization had been found from elemental analysis, molar conductivity, Infrared, Ultraviolet-visible, cyclic voltammetry, TG-DTA, magnetic measurements, DNA cleavage study and antimicrobial study. The elemental analysis suggested that the metal-ligand ratio is 2:1. The microbes Escherichia coli, Klebsiella pneumonia and Staphylococcus aureus were used to find out antimicrobial activity of binuclear metal complexes.
\end{abstract}

Keywords: Binuclear, 3, 3'-Dihydroxy benzidiene, 2-Amino thiophenol, Infrared, Electronic Spectra, DNA Cleavage Study, Antimicrobial Study

(C) RASĀYAN. All rights reserved

\section{INTRODUCTION}

In general, transition metals exercise many interesting properties and play a vital role in our life. Among transition metals, Copper and nickel are used in many fields. Copper has biostatic property. There is no chance for bacteria and many other forms of life in it. Copper alloys play a vital role as netting materials in the aquaculture industry due to their antimicrobial and bio fouling properties. It has strong structural and corrosion-resistant properties in Ocean environments. Copper protein has important roles in biological electron transport and oxygen transportation because of the interconversion of $\mathrm{Cu}(\mathrm{I})$ and $\mathrm{Cu}(\mathrm{II})$. The first pure metal carbonyl produced is Nickel tetracarbonyl. Nickel forms simple binary compounds with non metals including halogens. Many double salts containing nickel with another cation are acknowledged. Nickel can be part of a negatively charged ion called nickelate. Since nickel is present nearer to Copper and Ferrum, compounds with the same structure as the high-temperature superconductors that are known.

Transition metal complexes are not only important as potential drugs like treatment of cancer, but also used for analytical and diagnostic purposes in biological systems, in construction materials, tools, vehicles and as a catalyst. They are used as antimicrobial ${ }^{1-2}$, antioxidant ${ }^{3-4}$, antifungal ${ }^{5}$, antitumour ${ }^{6}$, antiinflammatory $^{7}$, anticancer ${ }^{8-9}$ and antibiotic ${ }^{10}$ applications. The ligands containing Nitrogen and sulphur can act as effective chelating agents for transition metal ions. ${ }^{11}$ Antibacterial activity against microbes such as Escherichia coli, Klebsiella pneumonia, and Staphylococcus aureus by metal complexes are calculated. ${ }^{12}$ We synthesized and characterized the novel binuclear complexes by means of 3,3'dihydroxy benzidiene and 2-amino thiophenol and $\mathrm{Cu}(\mathrm{II}), \mathrm{Ni}(\mathrm{II})$ salts.

\section{EXPERIMENTAL}

We purchased chemicals 3, 3'-dihydroxy benzidiene and 2-amino thiophenol from Loba chemicals. The solvents used were ethanol, DMSO and DMF. We completed the elemental analysis by using Carlo-Eraba

Rasayan J. Chem., 13(1), 521-528(2020)

http://dx.doi.org/10.31788/RJC.2020.1315538

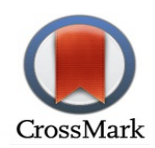


RASĀYAN J. Chem.

Vol. 13 | No. 1 |521 - 528| January - March | 2020

1106 instrument. Molar conductances of the metal complexes were analyzed with ELICO CM 185 conductivity Bridge. The Infrared spectra were collected by using the Perkin Elmer FT-IR-8300 model spectrometer. The UV-Visible spectra were recorded by means of Perkin Elmer Lambda- 25 between 200$700 \mathrm{~nm}$. The disc diffusion technique was used for antibacterial activities.

\section{Synthesis of Ligand}

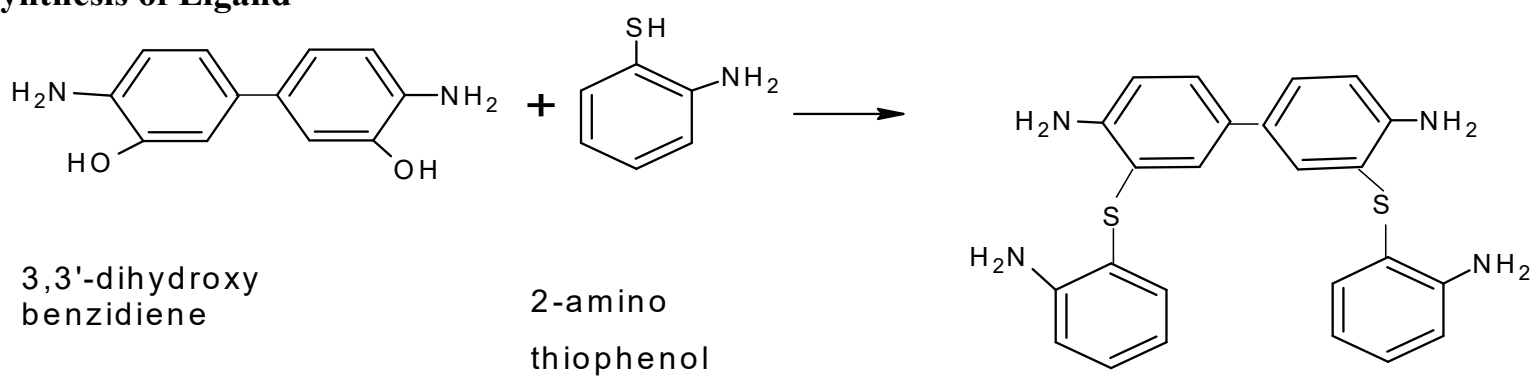

Scheme-1: Synthesis of Ligand

The solution of 3, 3'-dihydroxy benzidiene and solution of 2-amino thiophenol with alcohol were assorted slowly with constant stirring. This mixture was heated in $\mathrm{Rb}$ flask fitted with condenser for two hours. The precipitate was collected after cooling. It was purified many times with ethanol and further, it was desiccated.

\section{Synthesis of Metal Complexes}

Ligand and $\mathrm{CuCl}_{2} 2 \mathrm{H}_{2} \mathrm{O}$ were mixed and refluxed for 2 hours. It was chilled. The metal complexes were collected. After cooling, it was filtered and desiccated by using fused $\mathrm{CaCl}_{2}$. Similarly, ligand and another metal salt (i.e. $\mathrm{NiCl}_{2}$ ) were refluxed.

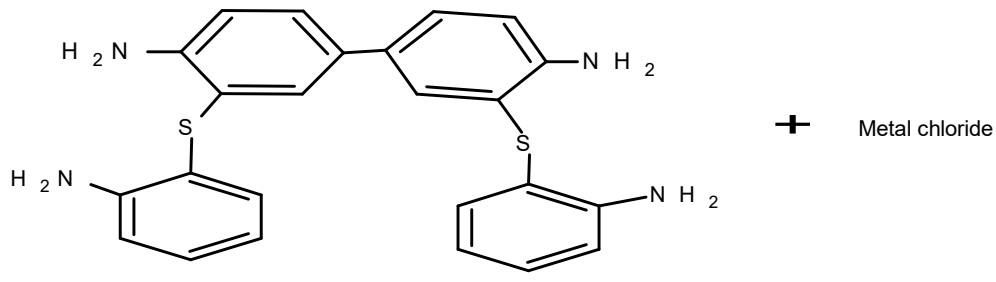

L ig a $n d$

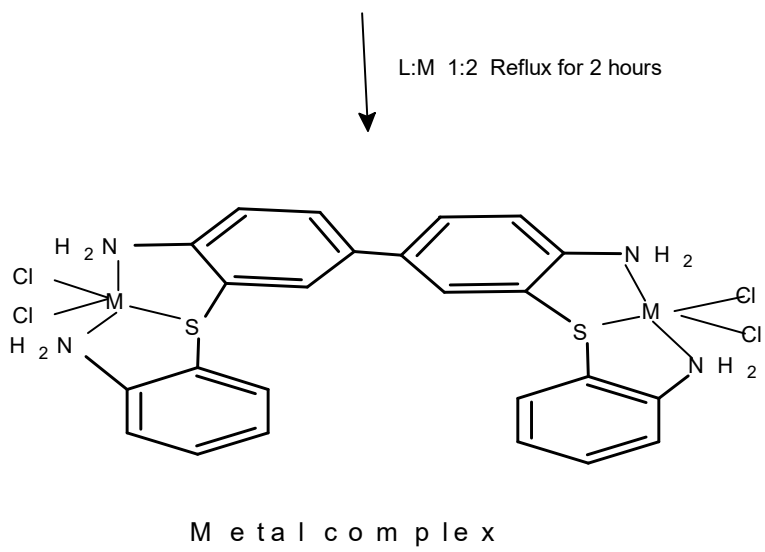

Scheme-2: Synthesis of Binuclear Metal Complex 
RASĀYAN J. Chem.

Vol. 13 | No. 1 |521 - 528| January - March | 2020

\section{Elemental analysis}

\section{RESULTS AND DISCUSSION}

The data of elemental analysis are mentioned in Table-1. The metal and ligand ratio 2:1 [M: L] is confirmed from the data. The formula is ML, where M means copper and nickel ions, while L means ligand. We have known that the theoretical values and experimental values are more or less the same.

Table-1: Elemental Analysis of the Metal Complexes

\begin{tabular}{|c|c|c|c|c|c|c|c|c|c|}
\hline \multirow{2}{*}{$\begin{array}{c}\text { Ligand/ } \\
\text { Complexes }\end{array}$} & \multirow{2}{*}{$\begin{array}{l}\text { Molecular } \\
\text { Weight }\end{array}$} & \multicolumn{2}{|c|}{$\% \mathrm{C}$} & \multicolumn{2}{|c|}{$\% \mathrm{H}$} & \multicolumn{2}{|c|}{$\% \mathrm{~N}$} & \multirow{2}{*}{$\begin{array}{c}\mu \text { eff } \\
\text { (B.M) }\end{array}$} & \multirow{2}{*}{$\begin{array}{c}\Lambda_{\mathrm{M}} \\
\left(\mathrm{Ohm}^{-1}\right. \\
\left.\mathrm{cm}^{2} \mathrm{~mol}^{-1}\right)\end{array}$} \\
\hline & & Cal. & Exp. & Cal. & Exp. & Cal. & Exp. & & \\
\hline$\left(\mathrm{C}_{24} \mathrm{H}_{22} \mathrm{~S}_{2} \mathrm{~N}_{4}\right)$ & 430.588 & 66.95 & 66.85 & 5.15 & 5.08 & 13.01 & 12.95 & & \\
\hline$\left[\mathrm{Cu}_{2}\left(\mathrm{C}_{24} \mathrm{H}_{22} \mathrm{~S}_{2} \mathrm{~N}_{4} \mathrm{Cl}_{4}\right)\right]$ & 699.492 & 41.21 & 41.12 & 3.17 & 3.11 & 8.01 & 8.10 & 1.61 & 12.41 \\
\hline$\left[\mathrm{Ni}_{2}\left(\mathrm{C}_{24} \mathrm{H}_{22} \mathrm{~S}_{2} \mathrm{~N}_{4} \mathrm{Cl}_{4}\right)\right]$ & 689.780 & 41.79 & 41.70 & 3.21 & 3.18 & 8.12 & 8.19 & 2.72 & 13.74 \\
\hline
\end{tabular}

\section{Conductivity Studies}

The metal complexes are dissolved in DMF initially. Molar conductivities are measured. The values of the complexes are mentioned in Table 1. It is proved that the copper and nickel complexes have a conductivity range of $12.41-13.74 \mathrm{Ohm}^{-1} \mathrm{~cm}^{2} \mathrm{~mol}^{-1}$ (Table-1). It shows the metal complexes are nonionic nature and non-electrolytes. It is confirmed that the chloride ions are in inside sphere. ${ }^{13}$

\section{Infrared Spectroscopy}

.The bands corresponding to carbon-carbon double bond $v(\mathrm{C}=\mathrm{C})$ appear within $1510-1550 \mathrm{~cm}^{-1}$. The bands obtained in the range $452-455 \mathrm{~cm}^{-1}$ corresponds to metal nitrogen bond $v(\mathrm{M}-\mathrm{N})$. The bands received in the range 340-347 $\mathrm{cm}^{-1}$ corresponds to metal sulphur bond $v(\mathrm{M}-\mathrm{S})$. The bands corresponding to metal Chloride bond $v(\mathrm{M}-\mathrm{Cl})$ appear within $350-355 \mathrm{~cm}^{-1} 14-17$. The regions are given in the following Table-2.

Table-2: Infrared Spectra of Ligand and Metal Complexes

\begin{tabular}{c|c|c|c|c}
\hline $\begin{array}{c}\text { Ligand/ } \\
\text { Complexes }\end{array}$ & $\begin{array}{c}(\mathrm{C}=\mathrm{C}) \\
\left(\mathrm{cm}^{-1}\right)\end{array}$ & $\begin{array}{c}(\mathrm{M}-\mathrm{N}) \\
\left(\mathrm{cm}^{-1}\right)\end{array}$ & $\begin{array}{c}(\mathrm{M}-\mathrm{S}) \\
\left(\mathrm{cm}^{-1}\right)\end{array}$ & $\begin{array}{c}(\mathrm{M}-\mathrm{Cl}) \\
\left(\mathrm{cm}^{-1}\right)\end{array}$ \\
\hline$\left(\mathrm{C}_{24} \mathrm{H}_{22} \mathrm{~S}_{2} \mathrm{~N}_{4}\right)$ & 1540 & 452 & 340 & 350 \\
\hline$\left[\mathrm{Cu}_{2}\left(\mathrm{C}_{24} \mathrm{H}_{22} \mathrm{~S}_{2} \mathrm{~N}_{4} \mathrm{Cl}_{4}\right)\right]$ & 1510 & 453 & 343 & 355 \\
\hline$\left[\mathrm{Ni}_{2}\left(\mathrm{C}_{24} \mathrm{H}_{22} \mathrm{~S}_{2} \mathrm{~N}_{4} \mathrm{Cl}_{4}\right)\right]$ & 1550 & 455 & 347 & 353 \\
\hline
\end{tabular}

\section{Ultraviolet Spectroscopy}

Structural elucidation was confirmed by UV spectra and they are shown in Figs.-1 to 3. Intra ligand charge transfer transition $\left(\pi \rightarrow \pi^{*}\right)$ was confirmed by one or two peaks obtained in the range of 290-320 $\mathrm{nm}$. The ligand to metal charge transfer transition was confirmed by the range of 380-390 nm. UV spectra of the mononuclear nickel (II) complex showed d-d transitions corresponding to $\mathrm{Ni}$ (II)-d $\mathrm{d}^{8}$ system in an octahedral field. The mononuclear copper (II) complex exhibited a distorted octahedral geometry due to low absorption peak at $535 \mathrm{~nm}$ and d-d transition. Only one broad absorption peak obtained in the binuclear copper (II) and nickel (II) complex in the region $515-655 \mathrm{~nm}$, because of one more metal ion present in complexes. ${ }^{18-20}$ The UV spectral data was given in the following Table-3.

\section{Cyclic Voltammetry}

The cyclic voltammetric technique was applied to know the reaction between metal complexes with DNA. The cyclic voltammograms (CV) of complexes $\left[\mathrm{Cu}_{2}\left(\mathrm{C}_{24} \mathrm{H}_{22} \mathrm{~S}_{2} \mathrm{~N}_{4} \mathrm{Cl}_{4}\right)\right]$ and $\left[\mathrm{Ni}_{2}\left(\mathrm{C}_{24} \mathrm{H}_{22} \mathrm{~S}_{2} \mathrm{~N}_{4} \mathrm{Cl}_{4}\right)\right]$ were got in DMF solution at a scan rate of $0.1 \mathrm{Vs}^{-1}$ and are shown in fig 4 . The potential range was from 1.2 to $-2.0 \mathrm{~V}$. The cathodic wave of the binuclear copper complex gives redox properties of the own units by them. Thus, there was a reduction of central $\mathrm{Cu}$ (II) to $\mathrm{Cu}(\mathrm{I})$ at $-0.80 \mathrm{~V}$ and irreversible copper reductions at $-1.50 \mathrm{~V}$. The support of two one-electron reductions is observed for the binuclear copper complex, suggesting that the two copper ions have some sort of interaction with each other. Same reports are obtained in the following complexes also $\left[\mathrm{Ni}_{2}\left(\mathrm{C}_{24} \mathrm{H}_{22} \mathrm{~S}_{2} \mathrm{~N}_{4} \mathrm{Cl}_{4}\right)\right]$ and $\left[\mathrm{Mn}_{2}\left(\mathrm{C}_{24} \mathrm{H}_{22} \mathrm{~S}_{2} \mathrm{~N}_{4} \mathrm{Cl}_{4}\right)\right]$. ${ }^{21-22}$ 
RASĀYAN J. Chem.

Vol. 13 | No. 1 |521 - 528| January - March | 2020

Table-3: UV-Vis Spectra of the Ligand and Complexes

\begin{tabular}{c|c|c|c|c}
\hline $\begin{array}{c}\text { Ligand/ } \\
\text { Complexes }\end{array}$ & $\begin{array}{c}\pi-\pi^{*} \\
{[\mathrm{~nm}]}\end{array}$ & $\begin{array}{c}\mathrm{n}-\pi^{*} \\
{[\mathrm{~nm}]}\end{array}$ & $\begin{array}{c}\text { L-M CT } \\
{[\mathrm{nm}]}\end{array}$ & $\begin{array}{c}\mathrm{d}-\mathrm{d} \\
{[\mathrm{nm}]}\end{array}$ \\
\hline$\left(\mathrm{C}_{24} \mathrm{H}_{22} \mathrm{~S}_{2} \mathrm{~N}_{4}\right)$ & 290 & 348 & 380 & -- \\
\hline$\left[\mathrm{Cu}_{2}\left(\mathrm{C}_{24} \mathrm{H}_{22} \mathrm{~S}_{2} \mathrm{~N}_{4} \mathrm{Cl}_{4}\right)\right]$ & 300 & 357 & 385 & 610 \\
\hline$\left[\mathrm{Ni}_{2}\left(\mathrm{C}_{24} \mathrm{H}_{22} \mathrm{~S}_{2} \mathrm{~N}_{4} \mathrm{Cl}_{4}\right)\right]$ & 320 & 365 & 390 & 620 \\
\hline
\end{tabular}

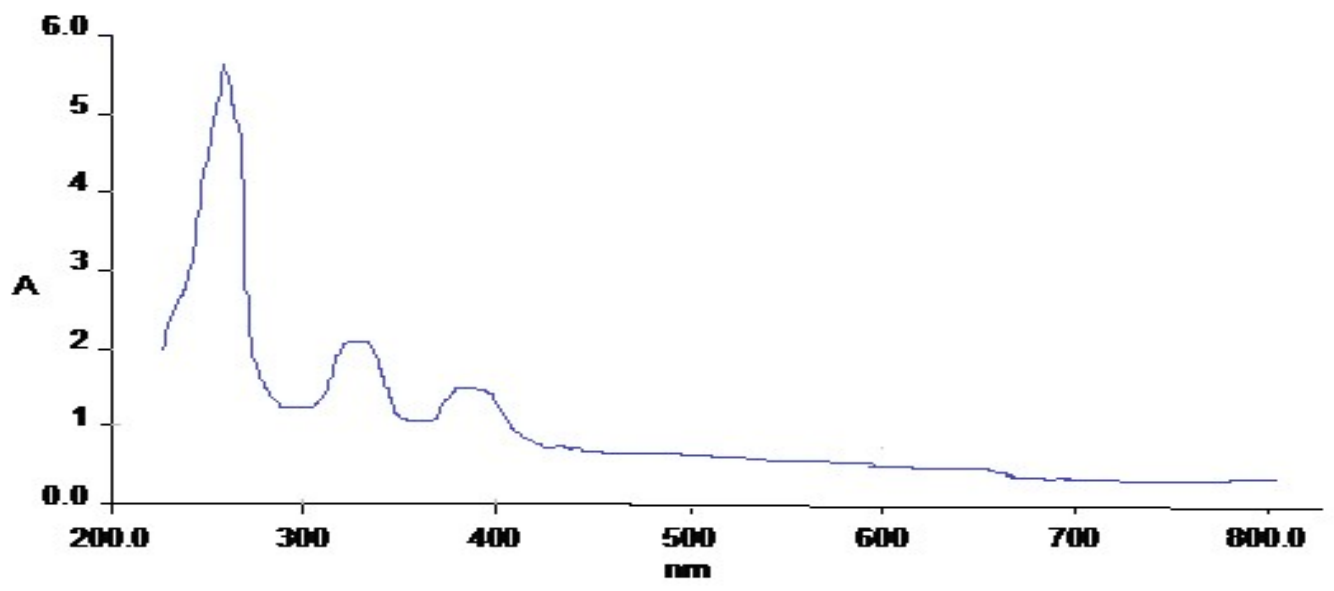

Fig.-1: UV Spectrum for Ligand $\left(\mathrm{C}_{24} \mathrm{H}_{22} \mathrm{~S}_{2} \mathrm{~N}_{4}\right)$

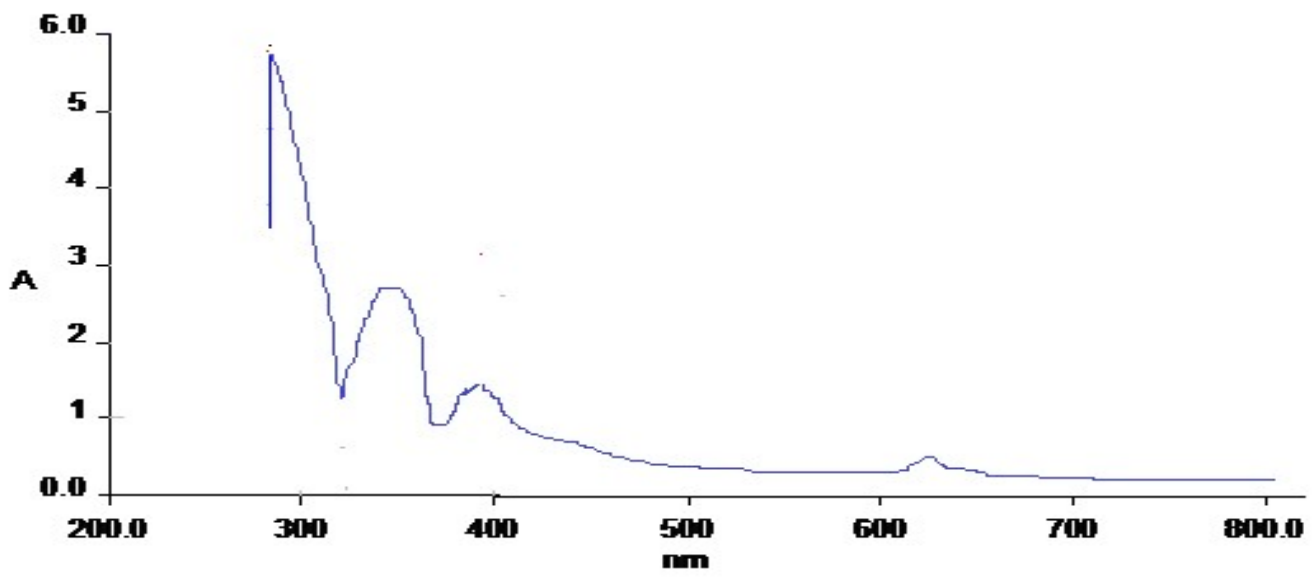

Fig.-2: UV Spectrum for $\left[\mathrm{Cu}_{2}\left(\mathrm{C}_{24} \mathrm{H}_{22} \mathrm{~S}_{2} \mathrm{~N}_{4} \mathrm{Cl}_{4}\right)\right]$

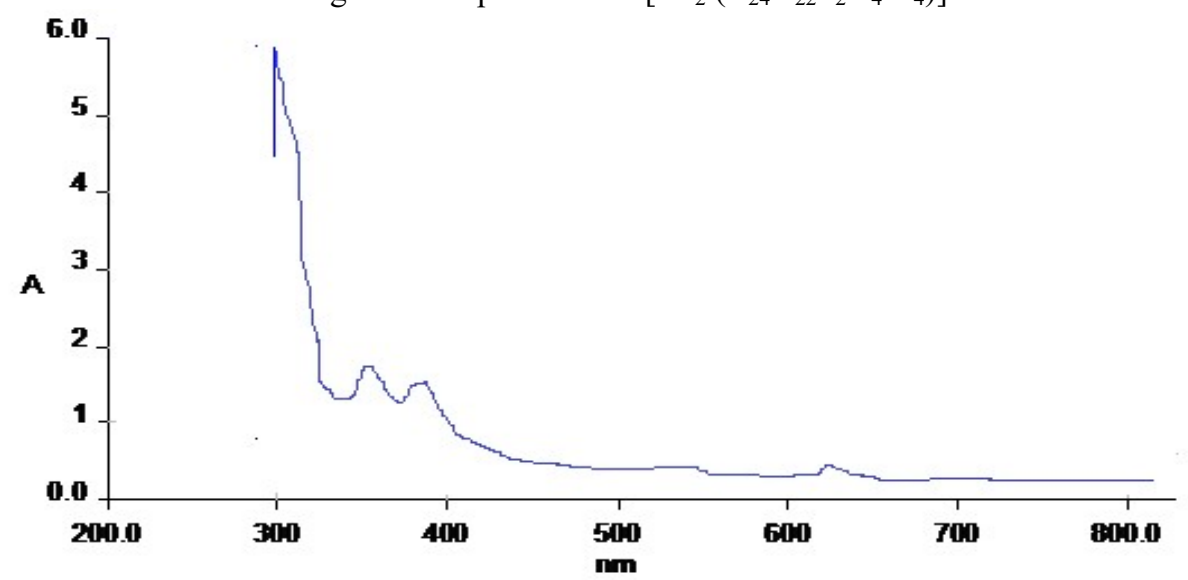

Fig.-3: UV Spectrum for $\left[\mathrm{Ni}_{2}\left(\mathrm{C}_{24} \mathrm{H}_{22} \mathrm{~S}_{2} \mathrm{~N}_{4} \mathrm{Cl}_{4}\right)\right]$ 
RASĀYAN J. Chem.

Vol. 13 | No. 1 |521 - 528| January - March | 2020

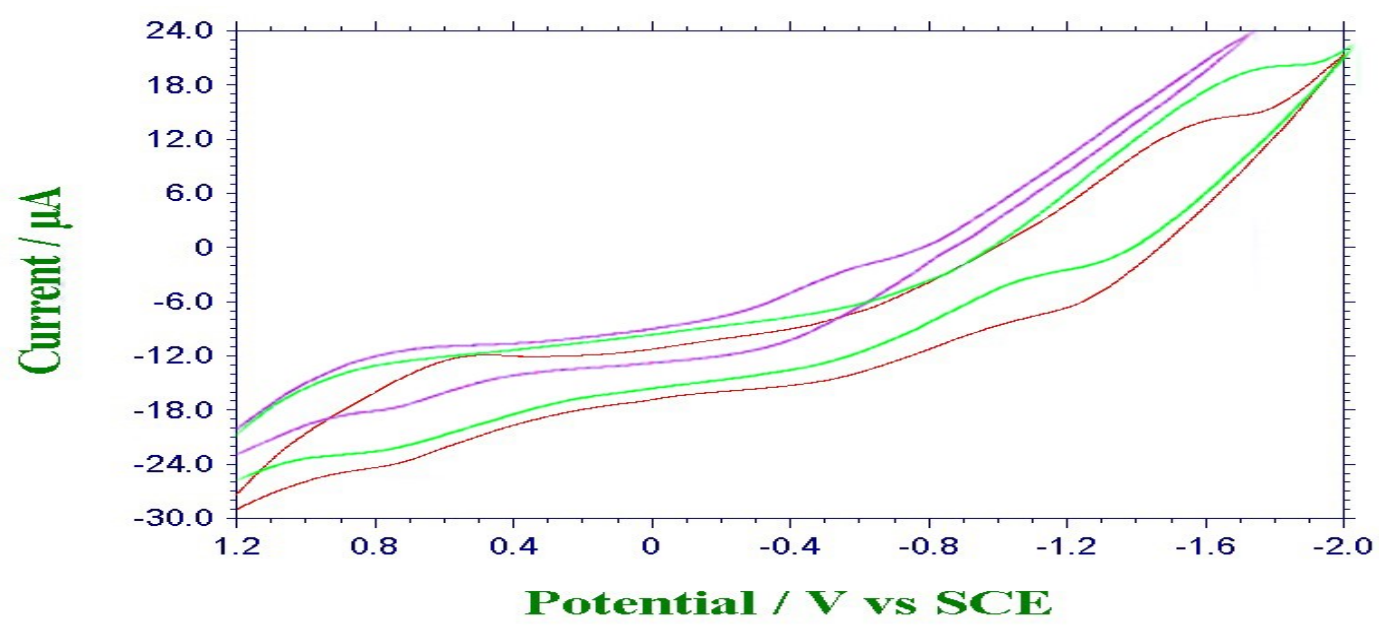

Fig.-4: Cyclic Voltagram of Ligand and complexes

Where, Violet- $\left(\mathrm{C}_{24} \mathrm{H}_{22} \mathrm{~S}_{2} \mathrm{~N}_{4}\right)$, Red- $\left[\mathrm{Cu}_{2}\left(\mathrm{C}_{24} \mathrm{H}_{22} \mathrm{~S}_{2} \mathrm{~N}_{4} \mathrm{Cl}_{4}\right)\right]$ and Green- $\left[\mathrm{Ni}_{2}\left(\mathrm{C}_{24} \mathrm{H}_{22} \mathrm{~S}_{2} \mathrm{~N}_{4} \mathrm{Cl}_{4}\right)\right]$

\section{Thermal analysis-TGA}

TG and DTG analyses were completed for the binuclear complexes. The temperature range was from ambient temperature to $900^{\circ} \mathrm{C}$. The decomposition steps of the synthesized compounds with the corresponding weight losses were compared. The thermal behaviour was mentioned in Table 4 . The results were more or less the same when compared with analytical data.

The binuclear Copper complex having the formula $\left[\mathrm{Cu}_{2}\left(\mathrm{C}_{24} \mathrm{H}_{22} \mathrm{~S}_{2} \mathrm{~N}_{4} \mathrm{Cl}_{4}\right)\right]$ was decomposed only one decomposition step. The loss of mass estimated was $68.12 \%$ (calculated loss of mass $=69.24 \%$ ). The temperature range was $150-660^{\circ} \mathrm{C}$. It was attributed to the loss of four $\mathrm{Cl}$, aniline and aromatic ligand groups. $^{23}$

The thermal decomposition of the binuclear Nickel complex with the molecular formula $\left[\mathrm{Ni}_{2}\left(\mathrm{C}_{24} \mathrm{H}_{22} \mathrm{~S}_{2} \mathrm{~N}_{4}\right.\right.$ $\left.\mathrm{Cl}_{4}\right)$ ] proceeded with three steps. The first step occurred within the temperature range of $170-330^{\circ} \mathrm{C}$. The estimated loss of mass was $20.56 \%$ (calculated loss of mass $=19.82$ ). This was because of the loss of four $\mathrm{Cl}$ groups. The second step occurred within the temperature range of $330-420^{\circ} \mathrm{C}$. The loss of mass was $21.79 \%$ (calculated loss of mass $=22.56 \%$ ). It was due to the loss of aromatic ligand groups. The third estimated loss of mass was $26.73 \%$ (calculated loss of mass $=25.88 \%$ ). The temperature range was 420 $630^{\circ} \mathrm{C}$. It was attributed to the liberation of aniline groups. The last step did not finish completely. Therefore, the last decomposition residue was not calculated. ${ }^{24}$

\section{Magnetic Measurements}

The structural investigation was confirmed by the magnetic moment values. It was measured at room temperature. The value for mononuclear copper (II) complexes was 1.68 B.M. Hence complexes were paramagnetic, which is responsible for the +2 oxidation state of copper (II) complexes. The magnetic moment of binuclear $\mathrm{Cu}$ (II) complexes are $1.57 \mathrm{BM}$ for the binuclear complex $\left[\mathrm{Cu}_{2}\left(\mathrm{C}_{24} \mathrm{H}_{22} \mathrm{~S}_{2} \mathrm{~N}_{4} \mathrm{Cl}_{4}\right)\right]$. The Binuclear copper (II) complexes had lower value compared to the mononuclear copper (II) complexes. The strong antiferromagnetic coupling that was established for binuclear copper (II) complexes were described as the good super exchange properties. Antiferromagnetic intramolecular interaction because of copper metal-copper metal interaction was the main reason for magnetic moment values of the binuclear complexes. ${ }^{25-26}$

\section{DNA Cleavage Study}

Electrophoresis method was used to analyse DNA cleavage study. Gel electrophoretic model is given in figure-5.Form I meant fastest migration for super coiled form. Form II meant super coils turned into slower moving open circular form if one strand was cleaved. Form III meant a linear nicked form was 
RASĀYAN J. Chem.

Vol. 13 | No. 1 |521 - 528| January - March | 2020

generated and migrated if both strand were cleaved. The dissimilar binding attraction of the compound to DNA was main reason for DNA cleavage efficiency. Copper compound degraded DNA wholly and showed efficient cleavage activity. Next to copper compound, efficient cleavage activity was shown by nickel compound. Both copper compound and nickel compound confirmed efficient cleavage activity ${ }^{27}$. 28

Table-4: TG/ DTA Data for Binuclear Complexes

\begin{tabular}{|c|c|c|c|c|c|}
\hline \multirow[t]{2}{*}{ Complexes } & \multirow{2}{*}{$\begin{array}{c}\text { TG Range } \\
\left({ }^{\circ} \mathrm{C}\right)\end{array}$} & \multicolumn{2}{|c|}{ Estimated (Calculated) (\%) } & \multirow[t]{2}{*}{ Assignment } & \multirow[t]{2}{*}{ Metallic Residue } \\
\hline & & $\begin{array}{l}\text { Loss of } \\
\text { Mass }\end{array}$ & $\begin{array}{c}\text { Total Loss of } \\
\text { Mass }\end{array}$ & & \\
\hline $\mathrm{Cu}$ & $150-660$ & $\begin{array}{c}68.12 \\
(69.24)\end{array}$ & $\begin{array}{c}68.12 \\
(69.24)\end{array}$ & $\begin{array}{l}\text { Loss of four } \mathrm{Cl} \\
\text { groups and } \\
\text { Loss of aromatic } \\
\text { group and } \\
\text { Loss of aniline } \\
\text { groups }\end{array}$ & $\begin{array}{c}\text { Decomposition is } \\
\text { in progress }\end{array}$ \\
\hline $\mathrm{Ni}$ & $\begin{array}{l}170-330 \\
330-420 \\
420-630\end{array}$ & $\begin{array}{c}20.56 \\
(19.82) \\
\\
21.79 \\
(22.56) \\
\\
26.73 \\
(25.88)\end{array}$ & $\begin{array}{c}69.08 \\
(68.26)\end{array}$ & $\begin{array}{l}\text { Loss of four } \mathrm{Cl} \\
\text { groups and } \\
\begin{array}{l}\text { Loss of aromatic } \\
\text { group and }\end{array} \\
\begin{array}{l}\text { Loss of aniline } \\
\text { groups }\end{array}\end{array}$ & $\begin{array}{c}\text { Decomposition is } \\
\text { in progress }\end{array}$ \\
\hline
\end{tabular}

S 112

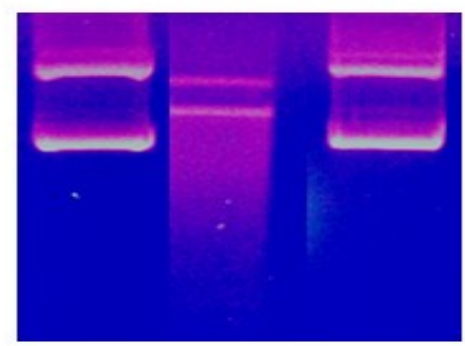

\section{Form I}

Form III

Form II

Fig.-5: Gel Electrophoretic Model of pUC18 DNA induced by $\mathrm{H}_{2} \mathrm{O}_{2}$ and Metal Compounds Lane s: Standard-pUC18DNA $+\mathrm{H}_{2} \mathrm{O}_{2}$; Lane 1: pUC18DNA $+\mathrm{Cu}$ compound $+\mathrm{H}_{2} \mathrm{O}_{2}$; Lane 2: pUC18DNA $+\mathrm{Ni}$

\section{Antimicrobial Activity}

$$
\text { compound }+\mathrm{H}_{2} \mathrm{O}_{2}
$$

Disc diffusion technique is used to calculate the antibacterial activity of the metal complexes. The microbes Escherichia coli, Klebsiella pneumonia and Staphylococcus aureus were used for antimicrobial activity. The minimum inhibitory concentration (MIC) values are given in Table 5. MIC values confirmed that the complexes have higher antimicrobial activity. ${ }^{29-30}$

Table-5: Antibacterial Activity of the ligand and metal Complexes

\begin{tabular}{|c|c|c|c|c|c|c|c|c|c|c|c|c|}
\hline \multirow[b]{3}{*}{ Compounds } & \multicolumn{4}{|c|}{ Klebsiella pneumoniae(mm) } & \multicolumn{4}{|c|}{ Escherichia coli(mm) } & \multicolumn{4}{|c|}{ Staphylococcus aureus(mm) } \\
\hline & \multicolumn{12}{|c|}{ Concentrations $(\mu \mathrm{g} / \mathrm{ml})$} \\
\hline & 25 & 50 & 75 & 100 & 25 & 50 & 75 & 100 & 25 & 50 & 75 & 100 \\
\hline$\left(\mathrm{C}_{24} \mathrm{H}_{22} \mathrm{~S}_{2} \mathrm{~N}_{4}\right)$ & 13 & 14 & 19 & 20 & 13 & 15 & 17 & 19 & 13 & 16 & 18 & 19 \\
\hline$\left[\mathrm{Cu}_{2}\left(\mathrm{C}_{24} \mathrm{H}_{22} \mathrm{~S}_{2} \mathrm{~N}_{4} \mathrm{Cl}_{4}\right)\right]$ & 12 & 15 & 18 & 19 & 12 & 14 & 17 & 19 & 12 & 15 & 17 & 18 \\
\hline$\left[\mathrm{Ni}_{2}\left(\mathrm{C}_{24} \mathrm{H}_{22} \mathrm{~S}_{2} \mathrm{~N}_{4} \mathrm{Cl}_{4}\right)\right]$ & 12 & 13 & 17 & 18 & 11 & 13 & 16 & 18 & 11 & 13 & 16 & 17 \\
\hline
\end{tabular}

The order of bacterial growth inhibition capacity of the binuclear complexes is $\mathrm{Cu}(\mathrm{II})>\mathrm{Ni}(\mathrm{II})$. Binuclear complexes are having larger MIC values against the growth of microorganisms when compared to 526 
RASĀYAN J. Chem.

Vol. 13 | No. 1 |521 - 528| January - March | 2020

standard Streptomycin. Chelation theory is used to explain the activity of the copper complex. The respiration process of the cell is collapsed by metal complexes and the synthesis of proteins is fully avoided and growth of the organisms was restricted. ${ }^{31-32}$

\section{CONCLUSION}

From the elemental analysis, molar conductance measurements, infrared and ultraviolet-visible spectra, cyclic voltammetry, TG-DTA, magnetic measurements of the complexes, the above-mentioned diagram is fixed and complexes are distorted octahedral. The molar conductance measurements confirm that the synthesised complex is non electrolytic in nature. The binuclear copper and nickel complexes were prepared from 3,3'-dihydroxy benzidiene and 2-amino thiophenol having $\mathrm{N}_{2} \mathrm{~S}$ donors. The antibacterial activity of the metal complexes was examined. The microbes Escherichia coli, Klebsiella pneumonia and Staphylococcus aureus were used to find out antimicrobial activity of binuclear metal complexes. Copper and nickel complexes have got more DNA cleavage activity and antimicrobial action.

\section{REFERENCES}

1. M. Roy, S.S. Devi, S. Roy, C.B. Singh, K.S. Singh, Inorganica Chimica Acta, 426,98(2015), DOI: $10.1016 /$ j.ica.2014.11.030

2. R. S. Joseyphus, M. S. Nair, Journal of Coordination Chemistry, 62, 319(2009), DOI: $10.1080 / 00958970802236048$

3. K. Sampath and C. Jayabalakrishnan, Synthesis and Reactivity in Inorganic, Metal-Organic, and Nano-Metal Chemistry, 45, 1145 (2015), DOI: 10.1080/15533174.2013.862688

4. J. E. Philip, S. A. Antony, S. J. Eeettinilkunnathil, M. R.P. Kurup and M. P. Velayudhan, Inorganica Chimica Acta, 469, 87 (2018), DOI:10.1016/j.ica.2017.09.006

5. V. Opletalova, D. S. Kalinowski, M.Vejsova, J. Kunes, M. Pour, J. Jampi'lek, V. Buchta, and D. R. Richardson, Chemical Research in Toxicology, 21, 1878 (2008), DOI: 10.1021/tx800182k

6. M. Shebl, Journal of Coordination Chemistry, 69, 199(2016), DOI: $10.1080 / 00958972.2015 .1116688$

7. T. R.Lakshman, J. Deb, I. Ghosh, S. Sarkar, T. K.Paine, Inorganica Chimica Acta, 486, 663 (2019), DOI:10.1016/j.ica.2018.11.025

8. D. Hegde, G. N. Naik, R. S. Vadavi, V. S. Kumar, D. A. Barretto, K. B. Gudasi, Inorganica Chimica Acta, 461,301 (2017), DOI: 10.1016/j.ica.2017.02.034

9. T. Yano, S. Hishida, M. Nakai, Yasuo Nakabayashi, Inorganica Chimica Acta, 454,162(2017), DOI: 10.1016/j.ica.2016.04.011

10. S. Nazir, J. Anwar, M. A. Munawar, J. I. Qazi, S.P. Best, M. Cheah, M. Yaseen, Inorganica Chimica Acta, 478, 166(2018), DOI:10.1016/j.ica.2018.04.002

11. K.H. Kumar Naik, B. Ashok, Nagaraja Naik, J. A. S. Mulla, A. Prakasha, Spectrochimica Acta Part A: Molecular and Biomolecular Spectroscopy, 141, 88(2015), DOI: 10.1016/j.saa.2014.11.068

12. Q.-B. Li, L.-W. Xue, W.-C. Yang and G.-Q. Zhao, Synthesis and Reactivity in Inorganic, MetalOrganic, and Nano-Metal Chemistry, 43,822 (2013), DOI:10.1080/15533174.2012.750342

13. B. Shafaatian and A. Baharian, Phosphorus, Sulfur and Silicon and the Related Elements, 192, 1102 (2017), DOI:10.1080/10426507.2017.1331232

14. M. Idešicova, R. Boc`a, Magnetism, Inorganica Chimica Acta, 408, 162 (2013),DOI: 10.1016/j.ica.2013.09.002

15. N. Shahabadiab, S. M. Filia \& M. Shahlaeic, Journal of Coordination Chemistry, 68, 3667 (2015), DOI: $10.1080 / 00958972.2015 .1078897$

16. J. Cisterna, V. Artigas, M. Fuentealba, P. Hamon, C.Manzur, V. Dorcet, J.-R. Hamon, D. Carrillo, Inorganica Chimica Acta, 462, 266 (2017), DOI:10.1016/j.ica.2017.04.001

17. S. Bharti, M. Choudhary \& B. Mohan, Journal of Coordination Chemistry, 71,284 (2018), DOI: 10.1080/00958972.2018.1424839

18. B. Roopashree, V. Gayathri \& H. Mukund, Journal of Coordination Chemistry, 65, 1354 (2012), DOI: 10.1080/00958972.2012.673123 
RASĀYAN J. Chem.

Vol. 13 | No. 1 |521 - 528| January - March | 2020

19. N. Singh, J. Niklas, O. Poluektov, K. M. V. Heuvelen, A. Mukherjee, Inorganica Chimica Acta, 455,221 (2017), DOI:10.1016/j.ica.2016.09.001

20. A. C. Ekenniaa, D. C. Onwudiweb \& A. A.Osowolec, Journal of Sulfur Chemistry, 36, 96 (2015), DOI: $10.1080 / 17415993.2014 .969731$

21. A. Bhattacharjee, S. Dey, P. Roy, Inorganica Chimica Acta, 490, 93(2019), DOI: 10.1016/j.ica.2019.03.005

22. J. Cisterna, V. Artigas, M. Fuentealba, P. Hamon, C. Manzur, V. Dorcet, J.-R. Hamon, D. Carrillo, Inorganica Chimica Acta, 462, 266 (2017), DOI:10.1016/j.ica.2017.04.001

23. O. A.M. Ali, S. M. El-Medani, M. R. A. Serea, A. S.S. Sayed, Spectrochimica Acta Part A: Molecular and Biomolecular Spectroscopy, 136, 651 (2015), DOI: 10.1016/j.saa.2014.09.079

24. R.R. Zaky, K.M. Ibrahim, I.M. Gabr, Spectrochimica Acta Part A: Molecular and Biomolecular Spectroscopy, 81, 28 (2011), DOI:10.1016/j.saa.2011.05.028

25. H. A. El-Boraey, O. A. EL-Gammal, Spectrochimica Acta Part A: Molecular and Biomolecular Spectroscopy, 138, 553 (2015), DOI:10.1016/j.saa.2014.11.015

26. J. Anacona, J. Santaella, Spectrochimica Acta Part A: Molecular and Biomolecular Spectroscopy, 115, 800 (2013), DOI:10.1016/j.saa.2013.06.107

27. M. Shebl, Spectrochimica Acta Part A: Molecular and Biomolecular Spectroscopy, 117,127 (2014), DOI:10.1016/j.saa.2013.07.107

28. M. A. Subhan, M. S. Rahman, K. Alam, M. M. Hasan, Spectrochimica Acta Part A: Molecular and Biomolecular Spectroscopy, 118,944 (2014), DOI: 10.1016/j.saa.2013.09.110

29. M. Shebl, S. M.E. Khalil, A. Taha, M.A.N. Mahdi, Spectrochimica Acta Part A: Molecular and Biomolecular Spectroscopy, 113,356 (2013), DOI:10.1016/j.saa.2013.04.131

30. M. Shebl, M. A. El-ghamry, S. M.E. Khalil, M. A.A. Kishk, Spectrochimica Acta Part A: Molecular and Biomolecular Spectroscopy, 126,232 (2014), DOI:10.1016/j.saa.2014.02.014

31. S.Jadhav, L.Khillare, M..Rai and A.Durrani, Rasayan Journal of Chemistry, 3, 27 (2010),

32. N. Ljubijankić, S. Begić, A. Ljubović-Dedeić, M. Stanković,I. Salimović-Bešić, M. Jadranin, B. Bencun and S. Ljubijankić, Rasayan Journal of Chemistry, 11, 1511 (2018), DOI: 10.31788/RJC.2018.1145021

[RJC-5538/2019] 